\title{
Agrowisata Sebagai Pengembangan Wisata Kawasan Waduk Kedung Ombo Dengan Pendekatan Arsitektur Ekologis
}

\author{
Taofiq, Muhammad Asrori, Tri Yuni Iswati \\ Program Studi Arsitektur \\ Jurusan Arsitektur Fakultas Teknik \\ Universitas Sebelas Maret Surakarta \\ Email : taofiqkage@gmail.com
}

\begin{abstract}
The design of Agrotourism in Kedung Ombo Region motivated by the development of tourism potential Kedung Ombo Grobogan, development of Grobogan agricultural potential, as well as the phenomenon of Grobogan farmers who sell agricultural products that still in the form of raw materials. Objectives to be achieved is to design an agro as the development of tourism potential of being owned by Grobogan on Kedung Ombo with objects in agriculture, fisheries, livestock, and industrial fields. Design issue is how to design agrotourism as a tourist development area Kedung Ombo with Ecological Architecture approach. The approach used in determining the design is to use the concept of Ecological Architecture applied in structuring the mass of the building in the site, determining the direction of view and orientation of the building that adapts to the movement of the sun, structuring monetary affairs which can save energy, the selection of environmentally friendly materials, the use of sunlight as a source of energy, the use of water in the form of an element and an artificial river as a natural cooling and water treatment plants, the use of several types

of vegetation as a natural shade on the site.
\end{abstract}

Keywords: Architecture, Agrotourism, Ecological Architecture, Kedung Ombo.

\section{PENDAHULUAN}

Waduk Kedung Ombo memiliki potensi untuk dikembangkan menjadi kawasan wisata. Menurut peraturan administrasi, Waduk Kedung Ombo hanya berfungsi sebagai penyedia air irigasi untuk daerah irigasi (DI) Sidurejo, DI Sedadi, DI Klambu, cadangan air baku untuk Kota Purwodadi dan Kota Semarang, dan PLTA. Namun seiring mulai berkembangnya wilayah Waduk kedung Ombo ini, sektor wisata mulai tumbuh secara alami. Dari waktu ke waktu jumlah pengunjung mengalami peningkatan. Potensi yang sudah dikembangkan yaitu perikanan dilengkapi dengan fasilitas pendukungnya seperti kereta kelinci, persewaan perahu, pasar ikan, dan area bermain. Hal inilah yang membuat pihak pengelola Waduk Kedung Ombo untuk membuat surat izin kepada direksi Perusahaan Umum (PERUM) Jasa Tirta 1 untuk menjadikan Waduk Kedung Ombo sebagai tempat wisata. Potensi Waduk Kedung Ombo lain yang bisa dikembangkan antara lain: wisata air, olah raga, dan area pengembangan Kawasan Waduk Kedung Ombo yang belum terolah. Menanggapi gagasan tersebut maka keluarlah Peraturan Pemerintah RI No. 46 Tahun 2010 tentang Perusahaan Umum (PERUM) Jasa Tirta 1 Pasal 14.

Pengembangan potensi pertanian yang dimiliki Kabupaten Grobogan merupakan hal yang perlu dilakukan. Berdasarkan perkembangan situasi dan kondisi Kabupaten Grobogan pada saat ini, dan terkait dengan Rencana Pembangunan Jangka Panjang Daerah (RPJPD) Kabupaten Grobogan tahun 2005-2025 maka untuk pembangunan Kabupaten Grobogan pada periode 5 tahun ke depan (tahun 2011-2016), disusun visi yaitu "Terwujudnya Kabupaten Grobogan sebagai daerah industri dan perdagangan yang berbasis pertanian, untuk mencapai masyarakat yang sehat, cerdas, dan lebih sejahtera". Kabupaten Grobogan sebagai daerah industri dan perdagangan yang berbasis pertanian mengandung pengertian bahwa Kabupaten Grobogan diupayakan untuk memiliki kemajuan pesat 
dan keunggulan di bidang industri pengolahan produk pertanian yang dihasilkan oleh daerah Kabupaten Grobogan itu sendiri dan diupayakan pula menjadi daerah penghasil komoditas perdagangan dari hasil pertanian tersebut.

Berdasarkan RTRW Kabupaten Grobogan tahun 2011-2031 tentang isu strategis di wilayah Kabupaten Grobogan yaitu pengembangan kawasan agropolitan. Potensi tersebar yang dimiliki Kabupaten Grobogan adalah sektor pertanian. Untuk meningkatkan produktifitasnya dalam rangka pengembangan wilayah, maka digunakan pendekatan konsep agropolitan. Isu selanjutnya yaitu perlindungan kawasan peruntukan hutan. Sebagian wilayah Kabupaten Grobogan merupakan kawasan hutan produksi tetap. Artinya bahwa kawasan ini berfungsi untuk pemenuhan syarat $30 \%$ luas kawasan hutan baik dalam lingkup wilayah kabupaten maupun wilayah Provinsi Jawa Tengah.

\section{METODE}

Metode yang digunakan untuk mencapai tujuan dan sasaran perencanaan dan perancangan adalah metode pemrograman arsitektur yang terdiri dari gagasan awal, temuan dan penelusuran masalah, pencarian data, pengolahan data dan informasi, konsep perencanaan, konsep perancangan, dan transformasi arsitektur.

Penulusuran masalah dimulai dengan melakukan survey langsung ke Kabupaten Grobogan dan lokasi Waduk Kedung Ombo. Permasalahan yang didapat yaitu bidang pertanian Kabupaten Grobogan yang menyimpan potensi untuk dijadikan salah satu obyek wisata dan potensi wisata Waduk Kedung Ombo yang belum dikembangkan.

Setelah permasalahan ditemukan dilakukan analisis perencanaan yaitu mengidentifikasi masalah yang ada berdasarkan konsep desain agrowisata yang diselesaikan dengan pendekatan Arsitektur Ekologis. Arsitektur Ekologis dipilih sebagai tema pendekatan karena prinsip-prinsip Arsitektur Ekologis bisa menjadi solusi dari masalah yang timbul dengan adanya agrowisata ini. Tapak terpilih dari agrowisata ini terletak di sekitar waduk sehingga memiliki peraturan tata guna lahan yang harus diperhatikan agar tetap mejaga kelestarian lingkungan sekitar. Dengan pendekatan yang tepat mampu mengurangi kerusakan lingkungan sekitar tapak.

Arsitektur Ekologis sebagai tema pendekatan dalam perancangan Agrowisata di Waduk Kedung Ombo juga sebagai batasan dalam menentukan bentuk massa, tata letak massa, tampilan, material, peruangan, serta pengolahan lansekap.

Analisis perancangan dilakukan dengan mengolah data yang telah terkumpul dan dikelompokkan berdasarkan pemrograman fungsional, performansi, dan arsitektural.

a. Pemrograman fungsional bertujuan untuk mengidentifikasi pengguna dari agrowisata ini yaitu pelaku kegiatan, jenis kegiatan, pola kegiatan, kebutuhan ruang, dan besaran ruang.

b. Pemrograman performasi menerjemahkan secara sistematik kebutuhan para pengguna Agrowisata di Waduk Kedung Ombo beserta fasilitasnya ke dalam persyaratan pemilihan tapak, persyaratan kebutuhan ruang, persyaratan besaran ruang, dan program ruang.

c. Analisis arsitektural merupakan tahap penggabungan dari hasil identifikasi kedua analisisi sebelumnya. Dalam proses ini akan menganalisis masalah pengolahan tapak, massa bangunan, peruangan, tampilan bangunan, struktur dan utilitas bangunan yang memenuhi kebutuhan agrowisata.

Setelah dilakukan analisis pemrograman fungsional, pemrograman performansi dan arsitektural, langkah selanjutnya yaitu melakukan sintesis. Sintesis merupakan tahap penggabungan dari referensi dan hasil analisis fakta lapangan sehingga didapat kesimpulan untuk memperoleh konsep perancangan yang sesuai dan ditransformasikan ke bentuk fisik yang diinginkan sesuai dengan pendekatan yang digunakan.

\section{ANALISIS}

\subsection{Analisis Lokasi}

a. Tujuan:

Mendapatkan lokasi yang sesuai dan mendukung sebagai area budidaya 
baik budidaya tanaman, ternak sapi ataupun perikanan.

b. Dasar pertimbangan:

1) Memiliki jenis tanah yang sesuai dengan kebutuhan tanaman yang akan dibudidayakan

2) Tidak mengganggu fungsi dari Waduk Kedung Ombo

3) Sesuai dengan peruntukan tata guna lahan sekitar waduk

4) Kemudahan dalam pencapaian

c. Hasil analisis:

Tapak terpilih yang akan dijadikan lokasi pembangunan agrowisata ini yaitu area pengembangan Waduk Kedung Ombo. Secara administrasi tapak terletak di Desa Ngrambat, Kecamatan Geyer, Kabupaten Grobogan. Luas tapak kurang lebih 8 Ha dengan batas pada sisi utara dan timur berupa Sungai Serang, jalan Purwodadi-Boyolali pada sisi selatan, dan PLTA pada sisi barat tapak (lihat Gambar 1).

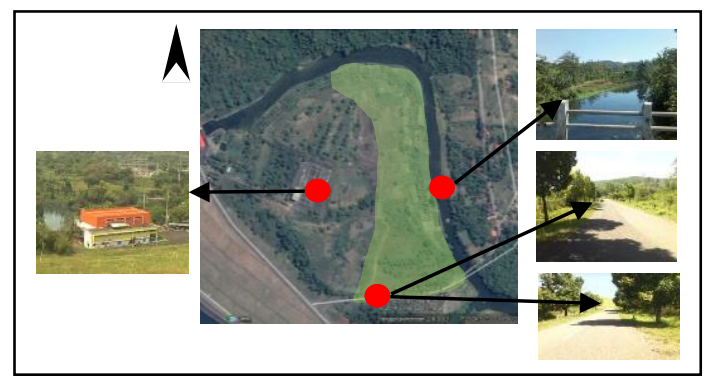

Gambar 1. Tapak Terpilih

Potensi yang dimilki dari area pengembangan tersebut adalah:

a. Memiliki akses jalan yang mudah dicapai oleh pengunjung

b. Lahan berkontur

c. Lahan terletak pada suatu lembah namun tapak sudah bisa terlihat dari kejauhan

d. Berbatasan dengan sungai yang bisa diambil potensinya

e. Terdapat vegetasi di dalam dan sekitar tapak

f. Jenis tanah yang ada sesuai dengan kebutuhan tanaman yang akan dibudidayakan (lihat Gambar 2)

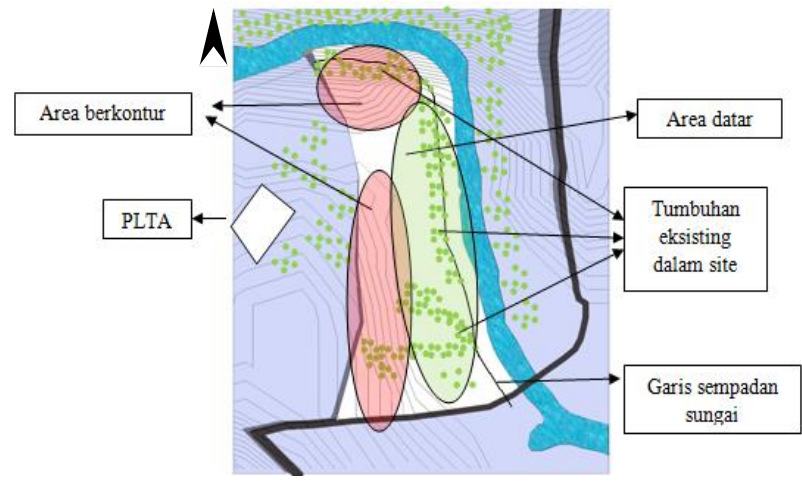

Gambar 2. Potensi Tapak

\subsection{Analisis Peruangan}

a. Tujuan: memperoleh jenis kebutuhan ruang dan besaran ruang

b. Dasar Pertimbangan:

Pengelompokan kegiatan dan pelaku kegiatan

c. Hasil analisa:

Pelaku kegiatan dari agrowisata ini adalah:

1) Pengunjung

2) Pengelola

3) Tenaga ahli

4) Karyawan

Berikut total luasan ruang yang dibutuhkan kelompok kegiatan:
a. Kelompok kegiatan penerima: $3.468,8 \mathrm{~m}^{2}$
b. Kelompok kegiatan agrowisata dan agroindustri: $14.391 \mathrm{~m}^{2}$
c. Kelompok kegiatan penunjang: $3.777 \mathrm{~m}^{2}$
d. Kelompok kegiatan service: 221 $\mathrm{m}^{2}$

\subsection{Analisis Pengolahan Tapak \\ 3.3.1 Analisis pencapaian}

a. Tujuan:

Menentukan main entrance in, main entrance out, side entrance dan area pedestrian

b. Dasar pertimbangan:

Kemudahan akses, pemisahan jalur keluar dan masuk kendaraan, arus kendaraan, keamanan dan kenyamanan pengunjung, tidak mengganggu jalur pedestrian

c. Hasil analisis 
Main entrance in berada di sisi selatan tapak karena dekat dengan jalan dan mudah diakses. Letak ME mudah dikenali oleh pengunjung karena pada posisi ini ME sudah bisa terlihat dari kejauhan walaupun tapak berada pada suatu lembah. Main entrance out berada di sisi selatan, terletak satu sisi dengan jalur masuk karena sisi ini merupakan sisi yang paling dekat dengan jalan utama. Side entrance berada di sisi barat dengan mempunyai pintu masuk tersendiri. Side entrance diperlukan agar tidak mengganggu kegiatan utama pengunjung pada jalur main entrance in. Perletakkan pedestrian pada tapak yaitu mengelilingi jalur main entrance in dan out (lihat Gambar $3)$.

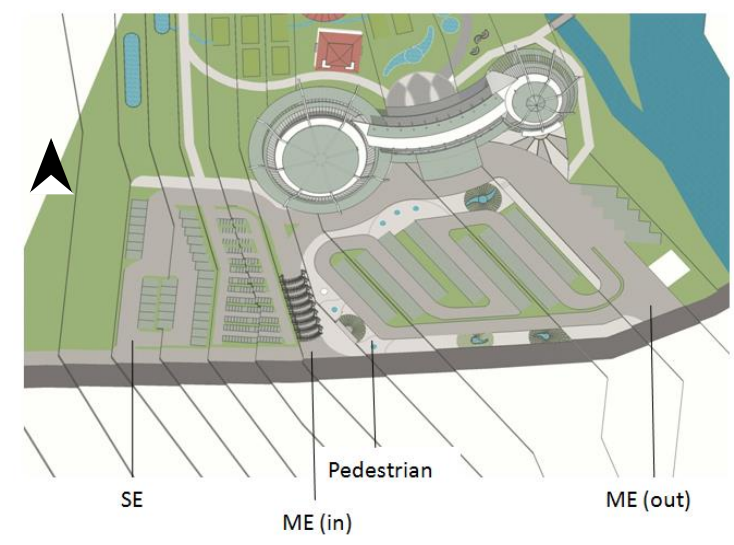

Gambar 3. Aplikasi ME, SE, dan Pedestrian

\subsubsection{Analisis massa bangunan}

a. Tujuan: Mendapatkan pola pengelompokan massa bangunan agrowisata

b. Dasar pertimbangan: cara perawatan tiap jenis komoditas budidaya, kemudahan bagi pengunjung untuk mendapatkan pemahaman mengenai perbedaan perawatan tiap jenis budidaya, perbedaan kegiatan yang ditawarkan, sirkulasi, aspek ekologis yaitu hubungan jenis tanah di dalam tapak dengan jenis tanaman budidaya. c. Hasil analisis:

Agrowisata yang dirancang menggunakan massa jamak. Hal ini dikarenakan tiap massa bangunan mewadahi kegiatan yang berbeda dan untuk membuat pengunjung mendapatkan pemahaman yang cukup tentang komoditas budidaya. Pengetrapan area budidaya tanaman pada tapak dipengaruhi oleh jenis tanah dan kebutuhan tanaman budidaya

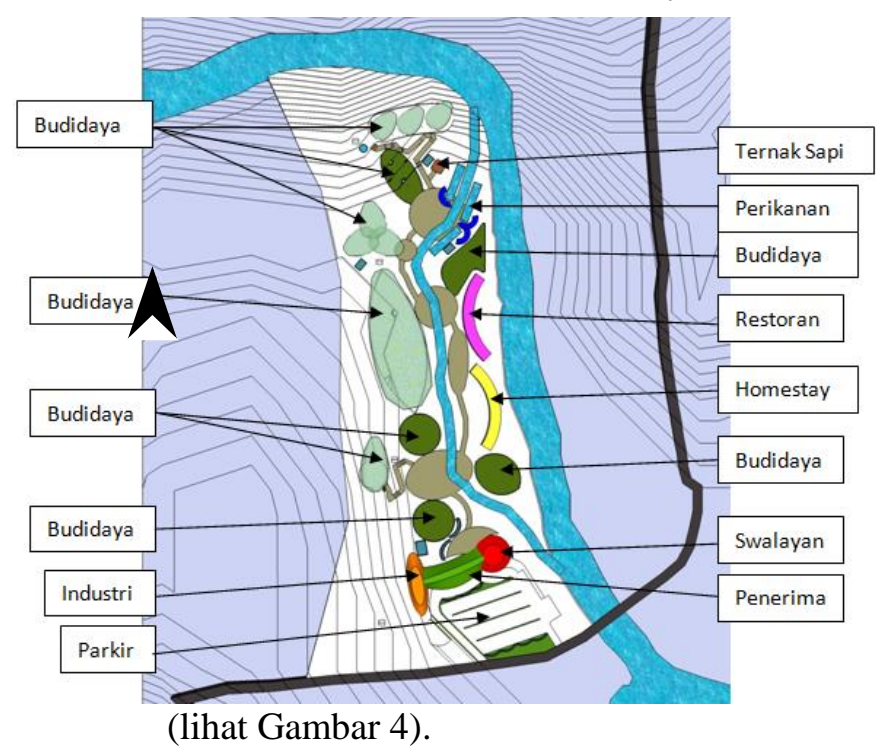

Gambar 4. Aplikasi Massa Bangunan

\subsection{Analisis bentuk massa bangunan}

a. Tujuan: Mendapatkan bentuk massa bangunan yang mampu mempresentasikan fungsi bangunan tersebut dan bentuk yang sesuai dengan tapak sekitar.

b. Dasar pertimbangan: fungsi bangunan dan kondisi tapak

c. Hasil analisis:

Obyek yang akan dirancang merupakan wisata yang dekat dengan alam sehingga bentuk yang dipilih untuk bangunan ini merupakan bentuk-bentuk yang cenderung organis. Bentuk yang sudah ada disekitar tapak juga digunakan yaitu bentuk badan bendungan Waduk Kedung Ombo

\subsection{Analisis faktor klimatologis}


a. Tujuan: Untuk pemecahan masalah akibat iklim terhadap tapak dan pertimbangan perletakan bangunan pada tapak

b. Dasar pertimbangan: arah datangnya sinar matahari, arah angin, dan aspek arsitektur ekologis

c. Hasil analisa:

Masalah yang berhubungan dengan iklim mempunyai beberapa pemecahan yaitu dari segi bukaan, barier, dan material. Bukaan berfungsi untuk menangkap sinar matahari ke dalam bangunan dan area budidaya indoor. Barier yang digunakan pada area agrowisata ini berupa vegetasi ataupun bangunan yang didesain sebaik mungkin sebagai penghalang sinar matahari ataupun angin yang merugikan bagi bangunan atau kegiatan yang ada di dalamnya. Material difungsikan sebagai solusi permasalahan bangunan dengan sinar matahari, di mana ia berperan untuk mengurangi sinar dan silau dalam bangunan.

\subsection{Analisis view dan orientasi}

a. Tujuan: Menentukan gambaran posisi bangunan yang mendapatkan perhatian masyarakat terbanyak berdasarkan kedudukan pengamat.

b. Dasar pertimbangan: letak jalan utama, view yang menarik, pergerakan matahari, dan arah datangnya pelaku kegiatan terbanyak.

c. Hasil analisis:

Massa jamak di dalam agrowisata ini memiliki kebutuhan tersendiri untuk view dan orientasi. Tiap massa memiliki fokus desain tersendiri untuk merespon view dan orientasi. Massa bangunan penunjang lebih mengutamakan view untuk memberikan kenyamanan bagi pengunjung. Massa bangunan budidaya lebih mengutamakan orientasi terhadap pergerakan matahari sehingga mampu menunjang kehidupan tanaman (lihat Gambar 5).

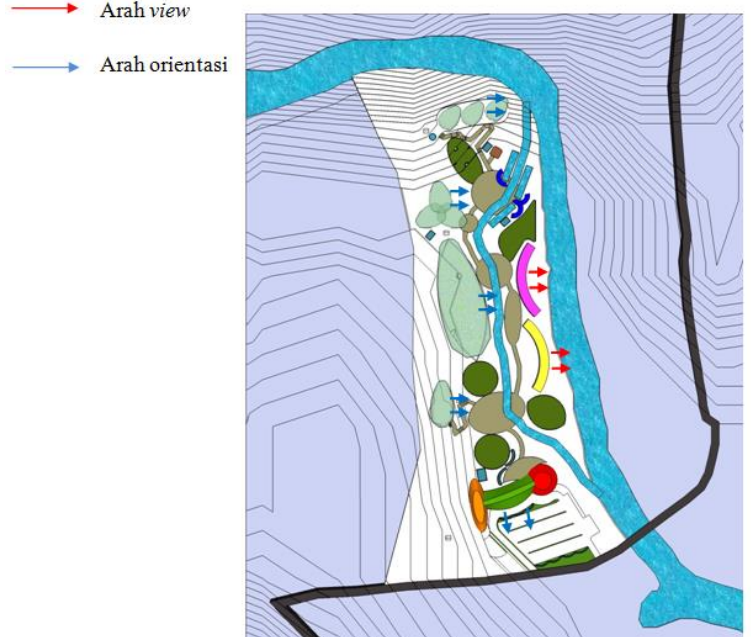

Gambar 5. Aplikasi View dan Orientasi Tiap Massa

\subsection{Analisis tampilan bangunan}

Tampilan bangunan agrowisata ini dirancang sedemikian rupa sehingga menimbulkan kesan atraktif, dinamis, memperkuat citra fungsi bangunan, serta tampilan yang merespon alam. Atraktif karena obyek yang dirancang merupakan obyek wisata (lihat Gambar 6).

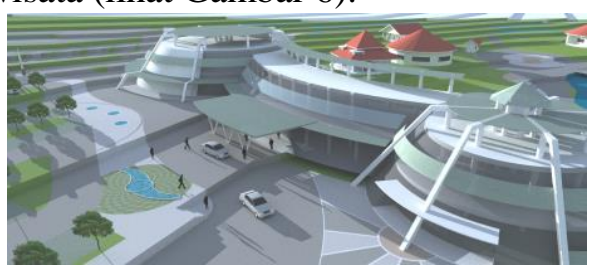

Gambar 6. Kesan Atraktif Pada Bangunan Penerima

Dinamis karena obyek wisata yang ditawarkan merupakan wisata alam (lihat Gambar 7).

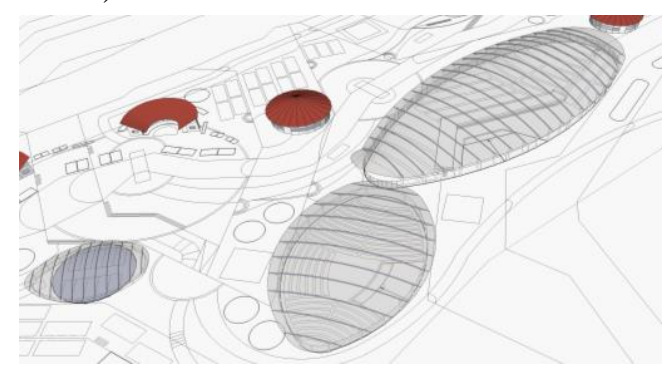

Gambar 7. Kesan Dinamis Pada Bangunan Budidaya Indoor

Memperkuat citra fungsi bangunan karena tampilan yang menggunakan unsur 
tanaman sehingga memperkuat citra bangunan sebagai area agrowisata (lihat Gambar 8).

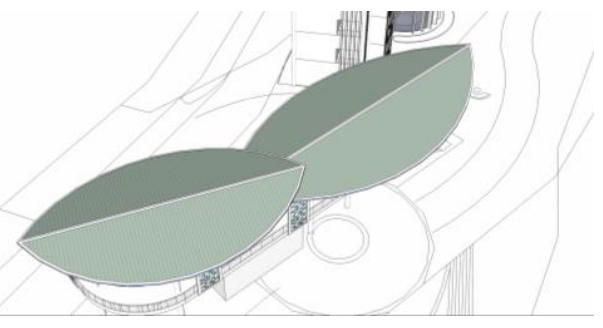

Gambar 8. Unsur Tanaman Pada Bangunan

Merespon alam karena pemakaian elemen bangunan yang mampu merespon alam seperti perletakan bukaan, pemilihan material, secondary skin, dan pemakaian pergola (lihat Gambar 9).

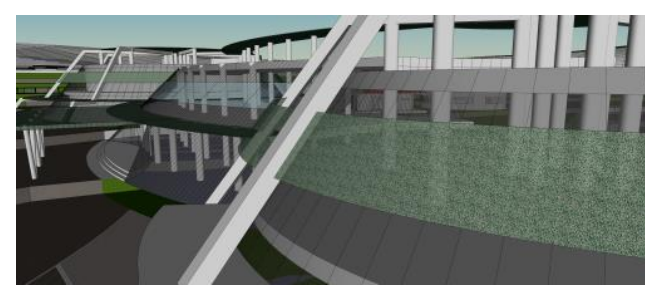

Gambar 9. Secondary Skin Pada Bangunan

\subsection{Analisis lansekap}

Elemen lansekap merupakan hal yang penting dalam wisata ini karena mampu memperkuat citra bangunan sebagai tempat wisata yang menggunakan obyek agro dalam perencanaannya. Unsur arsitektur ekologis yang diterapkan dalam lansekap ini yaitu unsur angin, energi, dan air.

\subsubsection{Vegetasi}

Elemen vegetasi merupakan elemen penting dalam perancangan karena penanaman dan penataan vegetasi tersebut dapat memberikan keuntungan di dalam tapak. Keuntungan tersebut misalnya terciptanya pemandangan yang indah, terciptanya udara yang segar di dalam tapak, serta fungsi-fungsi lain seperti peneduh, pengarah, dan ground cover. Vegetasi yang bersifat barier dan peneduh diletakkan pada area publik. Area publik yang memerlukan penataan vegetasi jenis ini yaitu parkir dan bangunan penerima. Vegetasi yang bersifat peneduh diletakkan pada area jalur sirkulasi antar massa bangunan dan sirkulasi area parkir. Untuk vegetasi yang berfungsi sebagai ground cover diletakkan pada taman dan area terbuka hijau. Ground cover diletakkan pada area taman yang tidak dapat diakses masuk oleh pengunjungdan juga diletakkan pada area terbuka hijau yang dapat digunakan sebagai ruang publik bagi pengunjung.

\subsubsection{Elemen air}

Air merupakan elemen yang sangat penting bagi agrowisata ini karena mempunyai beberapa fungsi. Air sebagai salah satu syarat utama bagi kelangsungan hidup tanaman budidaya. Penataan elemen air pada lansekap agrowisata bisa sebagai salah satu unsur estetika. Fungsi yang lain yaitu sebagai penghasil uap air yang mampu melembabkan udara di sekitar sumber air. Khusus untuk area budidaya, elemen air pastinya berfungsi sebagai sarana irigasi bagai tanaman. Elemen air yang digunakan dalam agrowisata ini yaitu kolam air, kolam pengolahan dan penampungan air, dan sungai buatan (lihat Gambar 10).

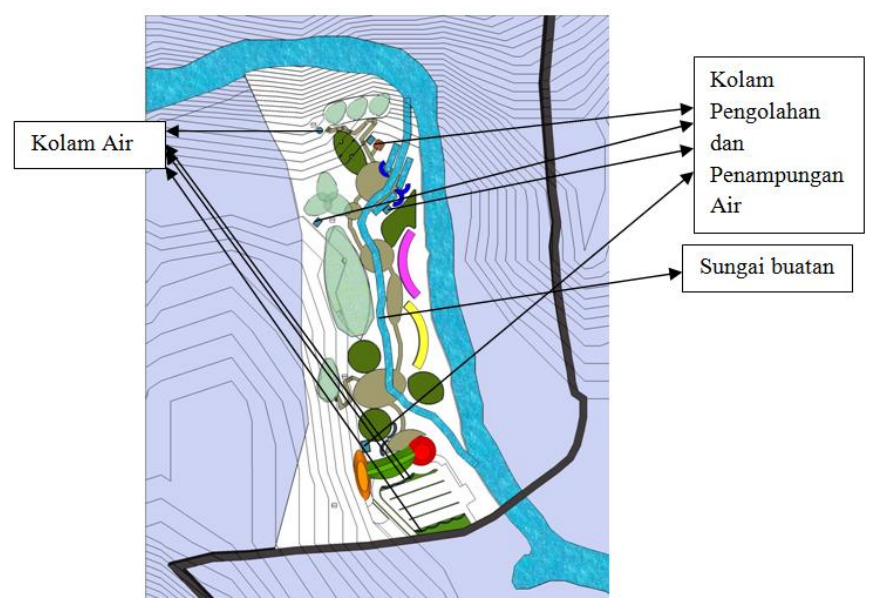

Gambar 10. Perletakan Elemen Air

\section{KESIMPULAN (KONSEP DESAIN)}

Agrowisata sebagai pengembangan wisata Kawasan Waduk Kedung Ombo 
merupakan pengembangan potensi wisata yang dimiliki Kawasan Waduk Kedung Ombo Kabupaten Grobogan menjadi suatu kawasan yang mewadahi kegiatan wisata, pertanian, peternakan, perikanan, dan industri dalam satu tempat dengan menerapkan pendekatan Arsitektur Ekologis.

Pendekatan Arsitektur Ekologis dipilih karena prinsip-prinsip di dalam arsitektur ekologis yaitu air, udara, tanah, dan api/energi (Frick, 1998) bisa digunakan untuk menyelesaikan masalah yang timbul karena adanya agrowisata ini. Penerapan arsitektur ekologis pada agrowisata ini bisa dilihat pada penataan massa bangunan dalam tapak (lihat Gambar 11), penentuan arah view dan orientasi bangunan yang menyesuaikan dengan pergerakan matahari (lihat Gambar 12), tampilan bangunan (lihat Gambar 13), serta penataan lansekap agrowisata (lihat Gambar 14).

Secara tampak kawasan massa bangunan agrowisata memiliki bentuk yang cenderung lengkung dan organis dengan pertimbangan yang telah disampaikan sebelumnya (lihat Gambar 15).

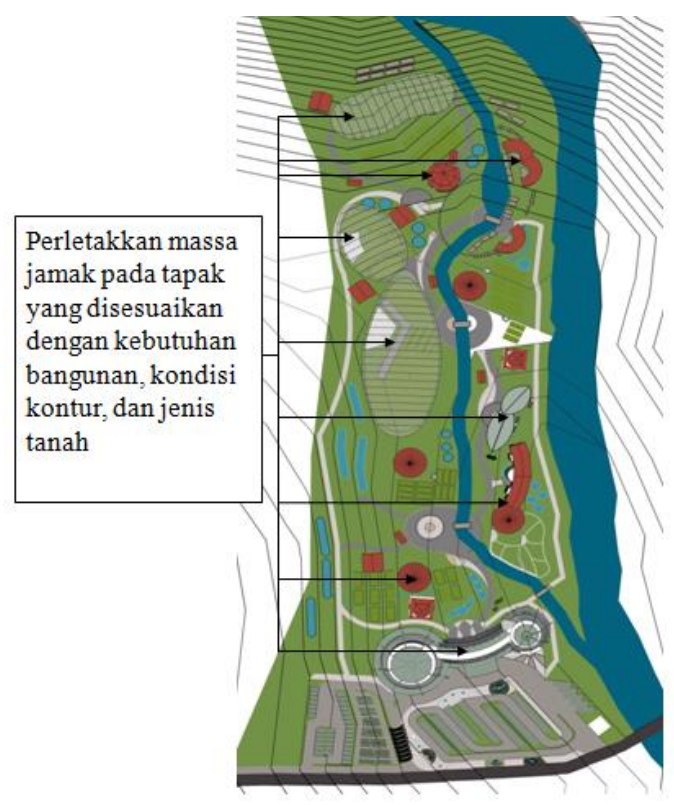

Gambar 11. Penataan Massa Agrowisata

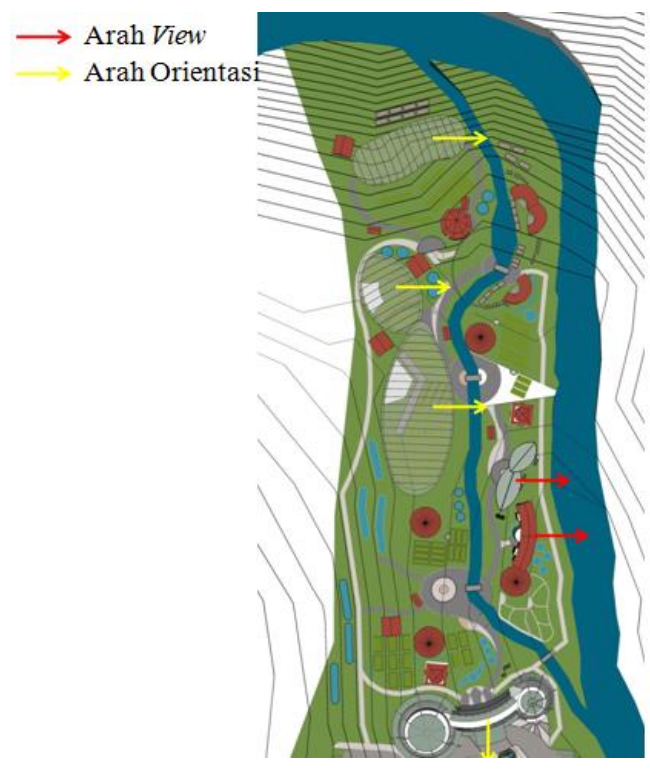

Gambar 12. View dan Orientasi

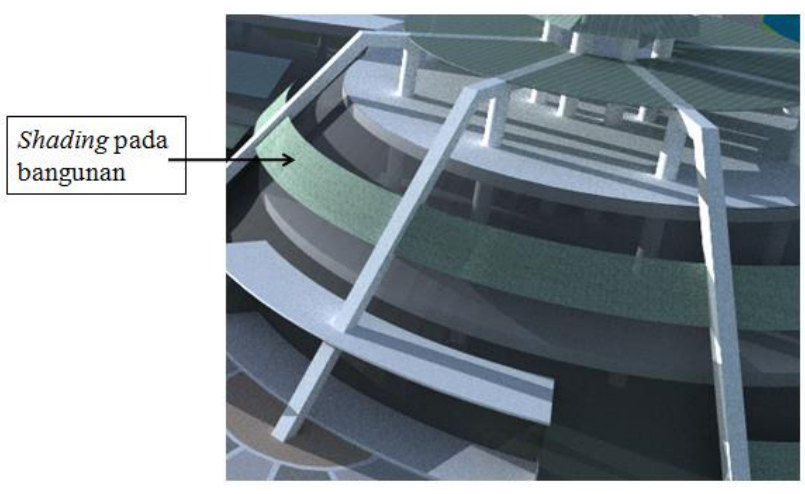

Gambar 13. Shading Bangunan 


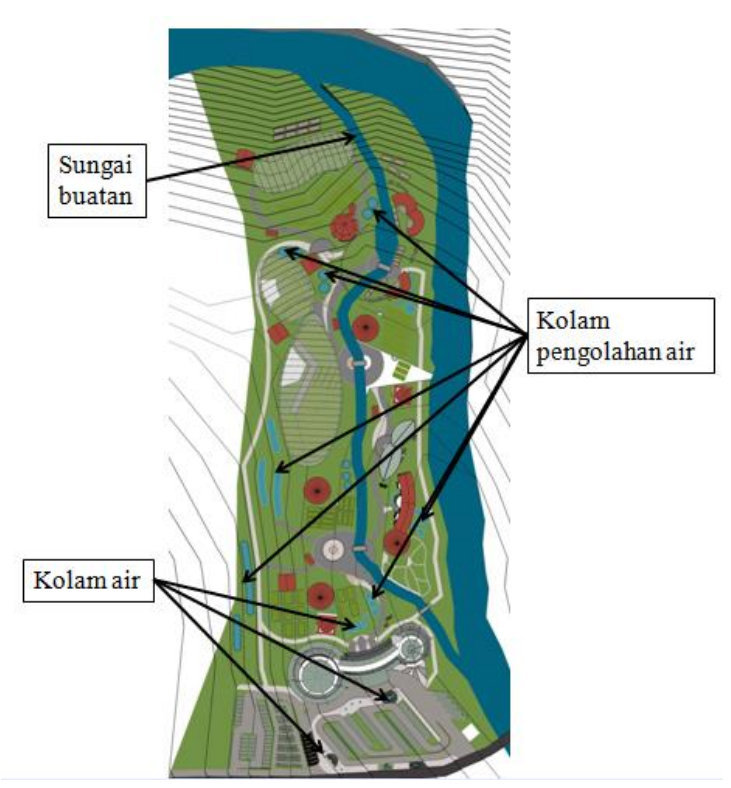

Gambar 14. Penataan Lansekap Agrowisata

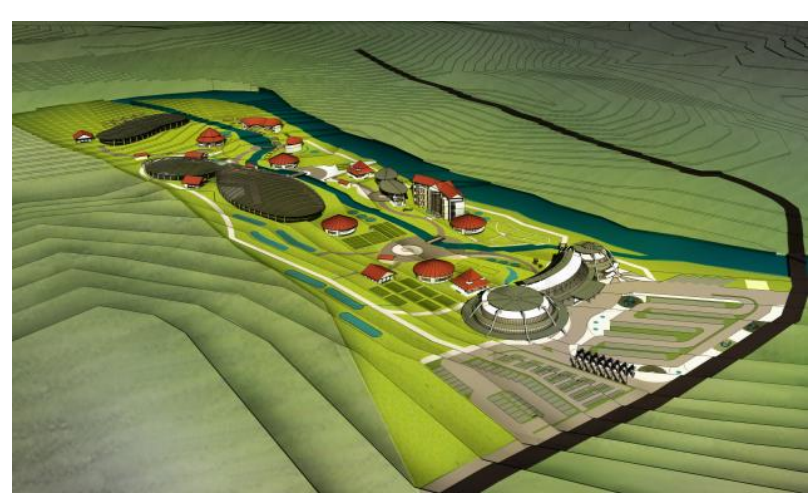

Gambar 15. Perspektif Eksterior

\section{REFERENSI}

Frick, Heinz \& Suskiyanto, Fx. Bambang. 1998. Dasar-Dasar Eko-Arsitektur. Kanisius. Jakarta

Peraturan Pemerintahan Republik Indonesia No. 46 Tahun 2010 Tentang Perusahaan Umum (PERUM) Jasa Tirta 1 